\title{
Erratum \\ The Embodied Self: Movement and Psychoanalysis
}

\author{
Susan Kierr
}

\section{Erratum to: Am J Dance Ther DOI 10.1007/s10465-007- 9027-6}

The name of the author was omitted from the table of contents page and from the book review.

The online version of the original article can be found under doi: $10.1007 / \mathrm{s} 10465-007-$ 9027-6.

Correspondence should be directed to Susan Kierr, American Dance Therapy Association NCC, 301 St. Paul St., Madisonville, LA, USA; e-mail: skdance@bellsouth.net. 